\title{
A review of sodium glucose co transporter 2 (sglt2) inhibitors for type 2 diabetes mellitus
}

\section{Introduction}

The global prevalence of diabetes in all age-groups has risen to nearly 670 million patients, or $9 \%$ of the population worldwide. ${ }^{1}$ In the United States, 29.1million (1 out of every 11) Americans have been diagnosed with diabetes and 86million (1 out of every 3 ) Americans are living with pre diabetes. ${ }^{2}$ Diabetes lowers life expectancy by up to 15 years, increases cardiac risk by two to four-fold, and leads to micro vascular and macro vascular complications including blindness, renal failure and lower limb amputations. ${ }^{3}$ Pharmacologic therapy and therapeutic lifestyle changes can effectively manage the disease and prevent or delay the progression of diabetic complications. Hypoglycemia and weight gain are common adverse effects of diabetes medications, and new classes of medications strive to minimize these events. The sodium glucose cotransporter 2 (SGLT2) inhibitors, or "flozins", have demonstrated modest weight loss and low risk of hypoglycemia when given as monotherapy. Three SGLT2 inhibitors have been approved by the FDA for the treatment of type 2 diabetes mellitus: Canagliflozin (Invokana $\AA$, Janssen Pharmaceuticals), Dapagliflozin (Farxiga ${ }^{\circledR}$, AstraZeneca/Bristol-Myers Squibb), and Empagliflozin (Jardiance ${ }^{\circ}$, Boehringer Ingelheim/Lilly).

\section{Pharmacology}

SGLT2 inhibitors inhibit the SGLT2 in the proximal nephron, subsequently reducing the reabsorption of filtered glucose. Excretion of glucose in the urine is increased by up to $80 \mathrm{~g}$ per day. ${ }^{4}$ These agents provide modest weight loss as the result of increased loss of urinary glucose and reduction in blood pressure by means of osmotic diuresis effects. ${ }^{5}$ An additional advantage of SGLT2 inhibitors is that these agents are effective at all stages of type 2 diabetes mellitus (T2DM) ${ }^{6,7}$ When therapy is advanced to combination basal/bolus insulin regimens, physicians may discontinue agents such as sulfonylureas and GLP-2 receptor agonists. ${ }^{7}$ SGLT2 inhibitors can be utilized as adjunctive therapy to improve glucose control and reduce the amount of insulin needed.

\section{Pharmacokinetics}

All of the SGLT2 inhibitors are available as an oral tablet formulation. The oral bioavailability of the SGLT2 inhibitors range from $60-78 \%$ and achieves maximum concentration 1-2hours after administration. The elimination half-life of this class of medication ranges from 10.2-13.1hours and have a once-daily dosing. Drug metabolism is primarily through glucuronidation by the liver and excretion of the drug is mainly by means of the urinary and fecal route. Since the SGLT2 inhibitors reduce the reabsorption of glucose in the kidney and reduce filtration rates, patients with renal impairment will require additional monitoring and/or dose adjustment. Table 1 provides a summary of the pharmacokinetic profile for the SGLT2 inhibitors. ${ }^{8-10}$

\section{Adverse event profile}

The risk of hypoglycemia is low when a SGLT2 inhibitor is administered as monotherapy. In combination therapy, the SGLT2 drug class may enhance the hypoglycemic effects with insulin and
Volume 4 Issue 2 - 2016

\author{
Eva YWong \\ Department of Pharmacy Practice, Marshall B. Ketchum \\ University, USA
}

Correspondence: Eva Y Wong, Department of Pharmacy Practice, Marshall B. Ketchum University, College of Pharmacy, 2575 Yorba Linda Blvd, Fullerton, USA, Tel 7|4.872.569I, Email ewong@ketchum.edu

Received: February 01, 2016 | Published: March 02, 2016

insulin secretagogues such as sulfonylureas. Prescribers should consider lowering the dose of insulin and monitoring for signs and symptoms of hypoglycemia when initiating SGLT2 adjunctive therapy. Genitourinary infections and polyuria were the most commonly reported adverse events and patients presenting with symptoms should be evaluated. Hypotension, dizziness, and doserelated increase in LDL cholesterol have also been reported. Fractures are rare, but have occurred in susceptible patients. Due to the renal mechanism of action of SGLT2 inhibitors, clinicians need to assess renal function as this class of medication is contraindicated in patients with severe renal function including eGFR $<30 \mathrm{~mL} / \mathrm{min} / 1.73 \mathrm{~m},{ }^{2}$ endstage renal disease or on dialysis.

Bladder cancer has been reported in patients treated with SGLT2 inhibitors in clinical trials, ${ }^{8-10}$ but there is insufficient data to determine if these cases were related to the effects of SGLT2 medications. Case reports of ketoacidosis have been identified in postmarketing surveillance, and the American Association of Clinical Endocrinologists (AACE) and American College of Endocrinology (ACE) have found in their review of these cases that the incidence of ketoacidosis to be infrequent. ${ }^{11}$ If ketoacidosis is suspected or if patient is at risk for ketoacidosis, the SGLT2 agent should be discontinued immediately.

\section{Efficacy}

SGLT2 inhibitors have demonstrated efficacy and safety in clinical trials for the treatment of patients with T2DM. ${ }^{12-25}$ SGLT2 inhibitors as monotherapy or in combination with another anti-diabetic treatment such as metformin or sulfonylurea have demonstrated efficacy in glycemic control with $\mathrm{HgA} 1 \mathrm{c}$ reduction of $0.5-1.0 \%$. Large metaanalysis studies of randomized controlled trials of these agents have found favorable effects on glycemic control, weight and blood pressure. ${ }^{26,27}$ The efficacy and safety of the SGLT2 inhibitors have not yet been directed compared with each other in the clinical trials. Data is lacking to support use for the treatment of T1DM at this time (Table 2). ${ }^{28}$

\section{Place in therapy}

SGLT2 inhibitors have been approved for the treatment of adults 
with T2DM. The safety and efficacy of SGLT2 inhibitors have not yet been established in the pediatric $(<18$ years of age) or type 1 diabetes population. These agents are also available in combination with other classes of medications, including CanagliflozinMetformin (Invokamet ${ }^{\circledR}$ ), Dapagliflozin-Metformin (Xigduo XR ${ }^{\circledR}$ ), Empagliflozin-Linagliptan (Glyxambi®).

The American Diabetes Association (ADA) guidelines recommend metformin (Glucophage $\AA$ ) as the initial agent for monotherapy due to high efficacy, low hypoglycemic risk, neutral or modest weight loss effects and low costs. ${ }^{8}$ The patient is reassessed after three months and if the HbAlc goal has not been achieved with metformin monotherapy, then an additional agent may be initiated. Dual therapy may consist of metformin and an agent from six classes of medications: sulfonyureas, thiozolidinediones, DPP-4 inhibitors, SGLT2 inhibitors, GLP-1 inhibitors or insulin (basal). Patient specific factors, patient preferences, medication costs, drug characteristics and HbAlc lowering effects should all be reflected upon when selecting the additional agent.

Doses of medications should be optimized with the consideration of patient's tolerability of potential dose-dependent side effects before proceeding to the addition of another agent. In conjunction with pharmacotherapy, ADA supports a patient-centered treatment regimen with continuous support for healthy eating, weight control, increased physical activity and diabetes self-management education (DSME). Table 3 provides a comprehensive summary of recommended monitoring.

Table I Pharmacokinetic profile

\begin{tabular}{|c|c|c|c|c|c|}
\hline SGLT-2 inhibitor & $\begin{array}{l}\text { Bioavailability } \\
\text { (Oral) }\end{array}$ & $T \max$ & $\begin{array}{l}\text { Elimination half-life } \\
\text { (TI/2) }\end{array}$ & Metabolism & Excretion \\
\hline $\begin{array}{l}\text { Canagliflozin } \\
\text { (Invokana®) }\end{array}$ & $65 \%$ & $\begin{array}{l}\text { I-2 } \\
\text { hours }\end{array}$ & $\begin{array}{l}\text { I00mg: I0.6hours } 300 \mathrm{mg}: \\
\text { 13.I hours }\end{array}$ & $\begin{array}{l}\text { Liver: by UGTIA9 and UGT2B4; minor } \\
\text { (7) CYP3A4 metabolism }\end{array}$ & $\begin{array}{l}\text { Feces } 41.5 \% \text {, } \\
\text { Urine } 33 \%\end{array}$ \\
\hline $\begin{array}{l}\text { Dapagliflozin } \\
\text { (Farxiga } ®)\end{array}$ & $78 \%$ & 2 hours & $\begin{array}{l}\text { 5mg: 1 } 2.2 \text { hours } 10 \mathrm{mg}: \\
12.9 \text { hours }\end{array}$ & $\begin{array}{l}\text { Liver: by UGTIA9; minor CYP-mediated } \\
\text { metabolism }\end{array}$ & $\begin{array}{l}\text { Urine } 75 \% \text {, } \\
\text { Feces } 21 \%\end{array}$ \\
\hline $\begin{array}{l}\text { Empagliflozin } \\
\text { (Jardiance } ® \text { ) }\end{array}$ & $>60 \%$ & $\begin{array}{l}1.5 \\
\text { hours }\end{array}$ & $\begin{array}{l}\text { I0mg: } 10.2 \text { hours } 25 \mathrm{mg}: \\
\text { 13.Ihours }\end{array}$ & $\begin{array}{l}\text { Liver: by UGT2B7, UGTIA3, UGTIA8, } \\
\text { UGT IA9 }\end{array}$ & $\begin{array}{l}\text { Urine } 54.4 \%, \\
\text { Feces } 41.2 \%\end{array}$ \\
\hline
\end{tabular}

Table $2 \mathrm{SGLT}_{2}$ drug profile

$\begin{array}{lllllll}\begin{array}{l}\text { Generic } \\ \text { name }\end{array} & \begin{array}{l}\text { Brand } \\ \text { name }\end{array} & \text { Dosing } & \text { Dose adjustment } & \begin{array}{l}\text { Pregnancy } \\ \text { category }\end{array} & \begin{array}{l}\text { HbAlc } \\ \text { reduction }\end{array} & \begin{array}{l}\text { Cost } \\ \text { (AWP) }\end{array}\end{array}$

\begin{tabular}{|c|c|c|c|c|c|c|c|}
\hline $\begin{array}{l}\text { Canagliflozin } \\
\text { FDA } \\
\text { Approved } \\
2013\end{array}$ & Invokana $®)$ & $\begin{array}{l}\text { Initial dose, } \\
100 \mathrm{mg} P O \\
\text { daily; may } \\
\text { increase to } \\
300 \mathrm{mg} P O \\
\text { daily }\end{array}$ & $\begin{array}{l}\text { eGFR } 45-60 \mathrm{ml} / \mathrm{min} / 1.73 \mathrm{~m}(2) \\
-\max 100 \mathrm{mg} / \text { day eGFR<45ml/ } \\
\mathrm{min} / \mathrm{I} .73 \mathrm{~m} \\
(2)-\text { Avoid use }\end{array}$ & C & $\begin{array}{l}\text { l00mg: } \\
0.77 \% \\
300 \mathrm{mg}: \\
1.03 \%\end{array}$ & $\begin{array}{l}\text { l00mg (30): } \\
\$ 435.67 \\
300 \mathrm{mg}(30): \\
\$ 435.67\end{array}$ & $\begin{array}{l}\text { Take before } \\
\text { first meal of } \\
\text { the day. }\end{array}$ \\
\hline
\end{tabular}

\begin{tabular}{|c|c|c|c|c|c|c|c|}
\hline $\begin{array}{l}\text { Dapagliflozin } \\
\text { FDA } \\
\text { Approved } \\
2014\end{array}$ & Farxiga $\circledast$ & $\begin{array}{l}\text { Initial dose, } \\
5 \mathrm{mg} \text { PO daily; } \\
\text { may increase } \\
\text { to IOmg PO } \\
\text { daily }\end{array}$ & $\begin{array}{l}\text { eGFR }<60 \mathrm{ml} / \mathrm{min} / \mathrm{I} .73 \mathrm{~m} \\
(2)-\text { Avoid use }\end{array}$ & C & $\begin{array}{l}\text { 5mg: } 0.8 \% \\
\text { IOmg: } 0.9 \%\end{array}$ & $\begin{array}{l}5 \mathrm{mg}(30): \\
\$ 435.68 \\
10 \mathrm{mg}(30): \\
\$ 4 \mid I .53\end{array}$ & $\begin{array}{l}\text { Take in the } \\
\text { morning, with } \\
\text { or without } \\
\text { food. }\end{array}$ \\
\hline $\begin{array}{l}\text { Empagliflozin } \\
\text { FDA } \\
\text { Approved } \\
2014\end{array}$ & Jardiance $®$ & $\begin{array}{l}\text { Initial dose, } \\
\text { I0mg PO } \\
\text { daily; may } \\
\text { increase to } \\
25 \mathrm{mg} \text { PO } \\
\text { daily }\end{array}$ & $\begin{array}{l}\text { eGFR }<45 \mathrm{ml} / \mathrm{min} / 1.73 \mathrm{~m} \\
\text { (2) - Avoid use }\end{array}$ & C & $\begin{array}{l}\text { IOmg: } 0.7 \% \\
25 \mathrm{mg}: 0.8 \%\end{array}$ & $\begin{array}{l}\text { IOmg (30): } \\
\$ 435.66 \\
25 \mathrm{mg}(30): \\
\$ 435.66\end{array}$ & $\begin{array}{l}\text { Take with or } \\
\text { without food. }\end{array}$ \\
\hline
\end{tabular}


Table 3 Monitoring parameters ${ }^{8}$

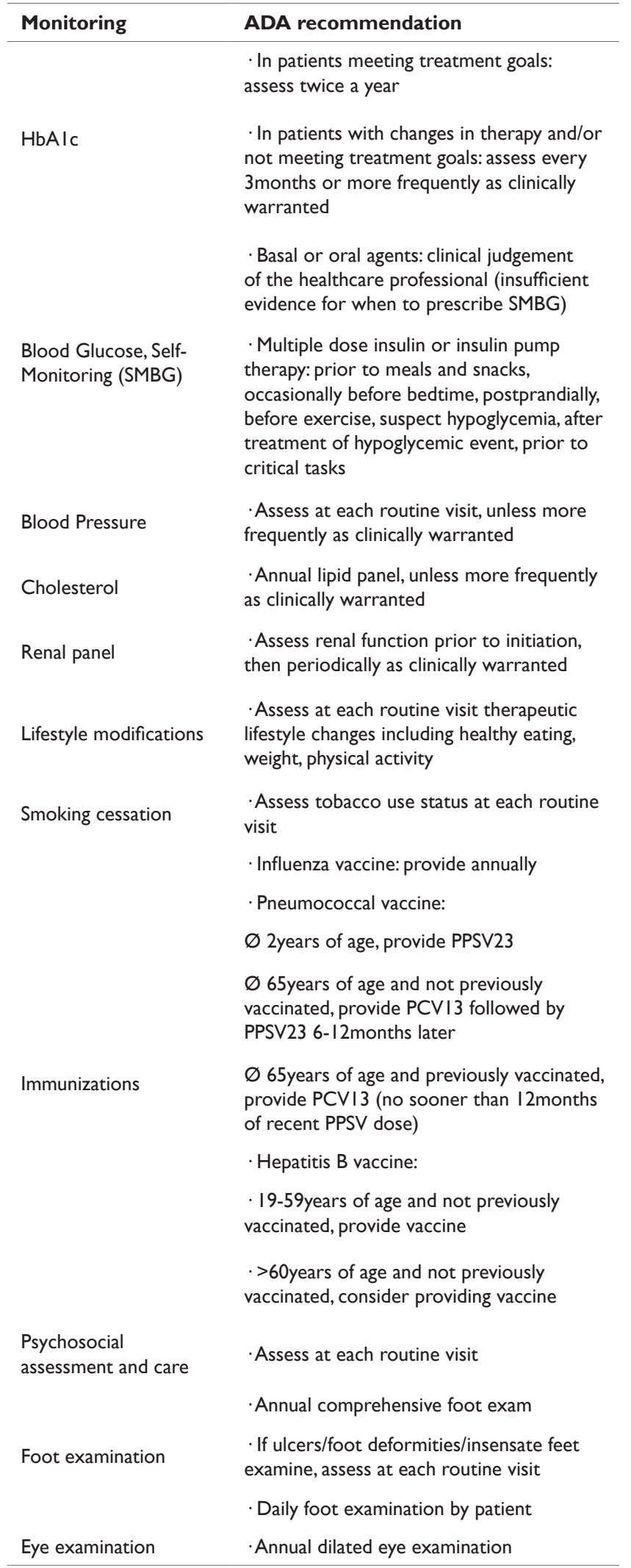

ADA, american diabetes association; PPSV23, pneumococcal polysaccharide vaccine 23; PCVI3, pneumococcal conjugate vaccine I3

\section{Summary}

The SGLT2 inhibitors are a new class of medications that have expanded the treatment options for T2DM. This class of medications offers adjunctive glycemic control and has favorable drug characteristics including once-daily frequency, oral route of administration, low risk of hypoglycemia and modest weight loss effects. New SGLT2 inhibitors, such as ipragliflozin (Suglat ${ }^{\circledR}$ ), tofogliflozin (Apleway ${ }^{\circledR}$ ) and luseogliflozin (Lusefi ${ }^{\circledR}$ ), are in the pipeline and may offer additional options to help achieve therapeutic goals. $^{29-3}$

\section{Acknowledgements}

None.

\section{Conflict of interest}

Author declares that there is no conflict of interest.

\section{References}

1. United Nations Department of Economic and Social Affairs. World's population prospects, the 2015 revision.

2. National Center for Chronic Disease Prevention and Health Promotion Centers for Disease Control and Prevention. National Diabetes Statistic Report, Atlantic, Georgia, USA; 2014.

3. U.S. Department of Health and Human Services. Healthy People 2020 Topics \& Objectives: Diabetes. Washington, USA; 2014.

4. Bays H. Sodium glucose co-transporter type 2 inhibitors: Targeting the kidney to improve glycemic control in diabetes mellitus. Diabetes Ther 2013;4(2):195-220.

5. Tikkanen I, Narko K, Zeller C, et al. Empagliflozin reduces blood pressure in patients with type 2 diabetes and hypertension. Diabetes Care. 2015;38(3):420-428.

6. Zhang L, Feng Y, List J, et al. Dapagliflozin treatment in patients with different stages of type 2 diabetes mellitus: effects on glycaemic control and body weight. Diabetes, obesity \& metabolism. 2010;12(6):510-516.

7. Standards of Medical Care in Diabetes-2015. Diabetes Care. 2015;38(Supp11):S1-S93.

8. Product Information: INVOKANA(TM) oral tablets, canagliflozin ora tablets. Janssen Pharmaceuticals, Inc. (per manufacturer), Titusville, USA; 2014.

9. Product Information: FARXIGA oral tablets, dapagliflozin oral tablets. Bristol-Myers Squibb Company (per manufacturer), Princeton, USA; 2014.

10. Product Information: JARDIANCE(R) oral tablets, empagliflozin oral tablets. Boehringer Ingelheim Pharmaceuticals (per manufacturer), Ridgefield, CT, USA; 2014.

11. Association of Scientific and Clinical Review. American Association of Clinical Endocrinology and American College of Endocrinology. AACE/ACE Scientific and Clinical Review: Association of SGLT2 Inhibitors and DKA. 2015.

12. Stenlof K, Cefalu WT, Kim KA, et al. Efficacy and safety of canagliflozin monotherapy in subjects with type 2 diabetes mellitus inadequately controlled with diet and exercise. Diabetes Obes Metab. 2013;15(4):372-382.

13. Stenlof K, Cefalu WT, Kim KA, et al. Long-term efficacy and safety of canagliflozin monotherapy in patients with type 2 diabetes inadequately controlled with diet and exercise: findings from the 52 week CANTATA-M study. Curr Med Res Opin. 2014;30(2):163-175. 
14. Yale JF, Bakris G, Cariou B, et al. Efficacy and safety of canagliflozin in subjects with type 2 diabetes and chronic kidney disease. Diabetes Obes Metab. 2013;15(5):463-473.

15. Lavalle-Gonzalez FJ, Januszewicz A, Davidson J, et al. Efficacy and safety of canagliflozin compared with placebo and sitagliptin in patients with type 2 diabetes on background metformin monotherapy: a randomised trial. Diabetologia. 2013;56(12):2582-2592.

16. Rosenstock J, Hansen L, Zee P, et al. Dual Add-on Therapy in Type 2 Diabetes Poorly Controlled With Metformin Monotherapy: A Randomized Double-Blind Trial of Saxagliptin Plus Dapagliflozin Addition Versus Single Addition of Saxagliptin or Dapagliflozin to Metformin. Diabetes Care. 2015;38(3):376-383.

17. Henry RR, Murray AV, Marmolejo MH, et al. Dapagliflozin, metformin $\mathrm{XR}$, or both: initial pharmacotherapy for type 2 diabetes, a randomised controlled trial. Int J Clin Pract. 2012;66(5):446-456.

18. Bailey CJ, Gross JL, Hennicken D, et al. Dapagliflozin add-on to metformin in type 2 diabetes inadequately controlled with metformin: a randomized, double-blind, placebo-controlled 102week trial. BMC Med. $2013 ; 11: 43$

19. Rosenstock J, Vico M, Wei L, et al. Effects of dapagliflozin, an SGLT2 inhibitor, on $\operatorname{HbA}(1 \mathrm{c})$, body weight, and hypoglycemia risk in patients with type 2 diabetes inadequately controlled on pioglitazone monotherapy. Diabetes Care. 2012;35(7):1473-1478.

20. Nauck MA, Del Prato S, Meier JJ, et al. Dapagliflozin versus glipizide as add-on therapy in patients with type 2 diabetes who have inadequate glycemic control with metformin: a randomized, 52-week, double-blind, active-controlled noninferiority trial. Diabetes Care. 2011;34(9):2015-2022.

21. Strojek K, Yoon KH, Hruba V, et al. Effect of dapagliflozin in patients with type 2 diabetes who have inadequate glycaemic control with glimepiride: a randomized, 24-week, double-blind, placebo-controlled trial. Diabetes Obes Metab. 2011;13(10):928-938.

22. Ferrannini E, Ramos SJ, Salsali A, et al. Dapagliflozin monotherapy in type 2 diabetic patients with inadequate glycemic control by diet and exercise: a randomized, double-blind, placebo-controlled, phase 3 trial. Diabetes Care. 2010;33(10):2217-2224.
23. Wilding JP, Norwood P, T'joen C, et al. A study of dapagliflozin in patients with type 2 diabetes receiving high doses of insulin plus insulin sensitizers: applicability of a novel insulin-independent treatment. Diabetes Care. 2009;32(9):1656-1662.

24. Liakos A, Karagiannis T, Athanasiadou E, et al. Efficacy and safety of empagliflozin for type 2 diabetes: a systematic review and metaanalysis. Diabetes Obes Metab. 2014;16(10):984-993.

25. DeFronzo RA, Lewin A, Patel S, et al. Combination of empagliflozin and linagliptin as second-line therapy in subjects with type 2 diabetes inadequately controlled on metformin. Diabetes Care. 2015;38(3):384-393.

26. Liu XY, Zhang N, Chen R, et al. Efficacy and safety of sodiumglucose cotransporter 2 inhibitors in type 2 diabetes: a meta-analysis of randomized controlled trials for 1 to 2 years. J Diabetes Complications. 2015;29(8):1295-1303.

27. Vasilakou D, Karagiannis T, Athanasiadou E, et al. Sodium-glucose cotransporter 2 inhibitors for type 2 diabetes: a systematic review and meta-analysis. Annals of internal medicine. 2013;159(4):262-274.

28. Chiang JL, KirkmanMS, Laffel LM, et al. Type 1 diabetes through the life span: a position statement of the American Diabetes Association. Diabetes Care. 2014;37(7):2034-2054.

29. Ohkura T. Ipragliflozin: A novel sodium-glucose cotransporter 2 inhibitor developed in Japan. World J Diabetes. 2015;16(1):136-144.

30. Kaku K, Watada H, Iwamoto Y, et al. Efficacy and safety of monotherapy with the novel SGLT2 inhibitor in Japanese patients with type 2 diabetes mellitus: a combined Phase 2 and 3 randomized, placebo-controlled, double-blind, parallel-group comparative study. Cardiovasc Diabetol. 2014;13:65.

31. Seino Y, Sasaki T, Fukatsu A, et al. Efficacy and safety of luseogliflozin as monotherapy in Japanese patients with type 2 diabetes mellitus. Curr Med Res Opin. 2014;30(7):1219-1230. 